\title{
Changing Times and Local Terms on the Rio Negro, Brazil: Amazonian Ways of Depolarizing Epistemology, Chronology and Cultural Change
}

\author{
Simeon Floyd
}

\begin{abstract}
Partway along the vast waterways of Brazil's middle Rio Negro, upstream from urban Manaus and downstream from the ethnographically famous Northwest Amazon region, is the town of Castanheiro, whose inhabitants skillfully negotiate a space between the polar extremes of 'traditional' and 'acculturated.' This paper takes an ethnographic look at the non-polarizing terms that these rural Amazonian people use for talking about cultural change. While popular and academic discourses alike have often framed cultural change in the Amazon as a linear process, Amazonian discourse provides resources for describing change as situated in shifting fields of knowledge of the social and physical environments, better capturing its non-linear complexity and ambiguity.
\end{abstract}

Keywords: Northwest Amazon; Brazil; Rio Negro; cultural change; acculturation; race and ethnicity; caboclo; indigenous discourse; lingua geral; nheengatú; supernatural; pajé; curupira

\section{Introduction}

This work explores issues of cultural change and adaptation based on the study of an Amazonian community that, in many ways, might be described as existing 'in between': in cultural terms, in between Brazilian national society and traditional indigenous society; in geographical terms, in between the rural forests and the urban centers; in linguistic terms, in between indigenous multilingualism and Portuguese monolingualism; in racial terms, in between extremes of Indianness and whiteness; in epistemological terms, in between the realms of magic and science. Existing in between is not just a location but a specific trajectory, since cultural change is often seen as linear and unidirectional, moving along a route from old traditional practices, beliefs and superstitions to new modern perspectives and scientific causational logics. That is why it is usual to speak of a community where 'they still believe in magic and shamanism' or 'they still speak the indigenous language,' but it is unusual to use the same terms to say, for example, that in the same community 


\section{$112 \quad$ S. Floyd}

'they still watch television' or 'they still believe in Western medicine' or 'they still speak Portuguese.' The inherent markedness of placing the features of membership and participation in the modern nation towards the left side of the timeline, where traditional cultural features are usually located, reveals a deeply held unconscious sense of inevitability in the nature and direction of change.

In discourse about indigenous culture in Brazil, rankings along the timeline are everywhere, operating like what Bakhtin terms a 'chronotope,' a pervasive and underlying chronology that circulates through discourse and structures random happenings into sequentiality (1981). As we floated past a river mouth on the Rio Negro, one traveler remarked, 'There are missionaries up there, civilizing the Indians'; relatively, in a larger town nearby he observed that 'the people here are already civilized.' While it may sometimes seem that such a perspective is limited to 'uneducated' popular discourse, anthropological discourse has historically been one of the primary sites of circulation of this linear evolutionary model of cultural change as a way of 'constructing its other' outside of present temporality; early ethnography was sometimes seen as a 'trip back in time' to previous stages of human development (Fabian, 1983). More than a few people have asked me if spending time in an indigenous community is like a visit to the 'stone age.' Others have questioned the authenticity of Indians who destabilize stereotypes by engaging in modern cultural styles and flows. An acquaintance in Manaus revealed a problematic political dimension to this tendency when he complained about a small group of indigenous people with a large land claim: 'A hundred kilometers of highway, and you are not allowed to stop your car, or they come out waving their spears at you. A hundred kilometers for just a few of them; and they aren't even real Indians - they all wear pants now.' The chronotope is persistent largely because those making claims on indigenous resources find it useful for discrediting indigenous counterclaims. At its heart it is an epistemological issue, as it deligitimizes indigenous knowledge by placing it in a positivist chronology where 'superstition' is progressively abandoned in favor of 'rationality.'

To describe the 'in between' state of rural Amazonian people not as an unidirectional progression away from Indianness but as a multidirectional space for constructing identity, where people become and un-become Indians across different places and moments, I will draw on Amazonian discourse forms as a resource for breaking up these polarities. I found that the Amazonian epistemology reflected in the discourse of Rio Negro peoples, unlike some Western paradigms, can deal quite nimbly with the contradictions and ambiguities that are basic components of culture as lived through negotiated social interactions, full of tensions that are challenging to resolve analytically. Through a discussion tracing the negotiations of persistent ideas and changing ways of thought in an Amazon town, I will also attempt to trace a certain history of anthropological thought about cultural change in which old ideas have recalled earlier points of articulation in bewilderingly non-linear fashion. I will revisit some particular points in this disciplinary history, and put them into dialogue with a school of thought whose origins are decidedly elsewhere. An ethnographic look at discursive patterns on the Rio Negro reveals some of the less binary ways that people in an Amazon community construct their distinct cultural configurations, sometimes as indios ('Indians'), sometimes caboclos 
('peasants'), sometimes ribeirinhos ('river-people'), sometimes as peoples from nossa comunidade ('our community') and of nossa costume, da gente ('our customs,' 'of [our] people'). In the following sections I will attempt to describe cultural changes and heterodoxies by using some of the resources provided by local terms, and to highlight some dynamic aspects of the classic problem of cultural contact and change among rural and indigenous groups in the Amazon.

\section{Upriver and Downriver}

The old ways of doing things, for the families of Castanheiro, are often geographically anchored upstream, towards the homes of the grandparents. In the early 20th century, when the chaos of rubber extraction finally died down, much of the middle Rio Negro was depopulated, historically present indigenous groups had been decimated and the opportunistic seringueiros had moved to other enterprises (Hemming, 1987, pp. 271-338). People from more distant indigenous communities on the upper Rio Negro tributaries were spared some of the pressures of the rubber boom; slowly they began to venture back downriver, founding communities like Castanheiro, whose people tell of ancestries from upriver Tukanoan and Arawak peoples.

The upper Rio Negro society from which the downriver migrants came in order to found Castanheiro is known for complex systems of regulations for health, hygiene, hunting, eating and food handling and production (Silva, 1977; Jackson, 1983). In the following passage, paraphrased from my field notes, Teresinha from Castanheiro speaks about the meaning of those traditions for her grandfather, indexing a past on the upper Rio Negro, as compared to their current relevance for her at present day in her middle Rio Negro community. She describes the changing significance of the traditional rules in a way that does not hold them in contrast as 'false' superstition against a 'true' scientific way of knowledge.

When I was a little girl our grandfather used to make us follow many rules. We could not eat cold or reheated food, or leave food out at night. We could not eat food without drinking water as well, for fear that our throats would burst. Some kinds of meat were forbidden, and it was prohibited to eat near women who had recently menstruated or gone through childbirth. If we did not follow the rules we could get sick with sarua or attract dangerous forest bichos, or we might get panema and have no luck at hunting or fishing. Grandfather used to insist on these things. Back then it used to be true, all of it, but these days I am beginning to think that it might be less true.

A non-binary division between true and untrue, a scale that would allow for gradient values of less true or more true, offers a certain grey area where contradiction and multiplicity are allowed to exist in relations of tension and partiality. Traditionally held and recently adopted perspectives need not come into conflict or be replaced one by the other in a linear trajectory of change. On the middle Rio Negro, cultural practices and perspectives of upriver people, like the grandfather's rules in the passage above, can operate in concert with elements associated with downriver cultural patterns.

Far downstream from the indigenous communities of the Rio Negro are the populous cities of Manaus and Belém and hundreds of rural communities featuring 
an intricate collage of the Iberian, Tupían and African elements of Brazilian cultures. While many people of the middle Rio Negro can trace a recent line of descent to further upriver communities, the same people share much with downriver cultures as well. From Catholic priests to Portuguese and Brazilian colonists to prospectors seeking rubber or gold, the Rio Negro has seen its share of influences and immigration from downstream. Yet the downstream cultures had long before passed through complicated processes of contact and adaptation, and the incoming populations of mestiços or caboclos showed many American features alongside their European ones. One way of describing this mesh of traditions is to employ concepts such as 'fusing,' as Charles Wagley does in his classic ethnography Amazon Town when he describes the Tupian elements of Brazilian culture, including the Tupian trade language that people in Castanheiro speak today:

With this language, many traditions of Tupí origin spread throughout Amazonia even in areas not inhabited in aboriginal times by Tupían peoples. European concepts transmitted through língua geral were subjected to modification and accretion of aboriginal details in the process. The Christian God and the Devil were given the names (in língua geral) of Tupan and Juruparí. Both took on characteristics of aboriginal supernaturals of these same names. Witches and werewolves of European medieval belief were easily identified with Tupí forest demons and were also given aboriginal names. Thus, along with Iberian patterns imposed upon and taught to the Amazon peasant population by their European conquerors, a body of aboriginal culture patterns has persisted in rural culture throughout the Brazilian Amazon. These aboriginal patterns have fused with the fabric of the predominantly Iberian culture to form a way of life, a culture distinctive of the region and well adapted to the particular Amazon environment. (Wagley, [1953] 1964, p. 42)

The 'body of aboriginal culture patterns' of Tupían peoples was subsequently brought to the other indigenous peoples of the Amazonian interiors, bringing Tupí language and culture into contact with other Amerindian languages and cultures. Particularly focusing on the case of language, it is interesting to note that today one of the last places that the modern form of coastal Tupí is spoken is thousands of miles inland on the Rio Negro, where Tukanoan, Arawak, Nadahup ('Makú') and Yanomami people continue to use the language of the historical Tupian and mestiço colonists as a first language or as a contact language. ${ }^{2}$ Far downstream the huge and chaotic urban area of Manaus, a Tupi-speaking region throughout the 19th century, now spreads Portuguese upriver on ships and barges to Rio Negro towns. Some families have undergone two processes of language shift within two generations, from Tukano to Tupian lingua geral, and then to Portuguese. In a place like Castanheiro there are no easy divisions between the indigenous and the non-indigenous, nor linear transitions from one to the other, and it is nearly impossible to rigidly demarcate Tukanoan, Tupian, Arawakan and Portuguese patterns and practices. The boats that have pulled in and out of the harbor brought ideas, people and things in flows and currents of high and low water, storm and calm.

The town of Castanheiro slopes down to the north banks of the Rio Negro, where a beach of granite bedrock looks out towards another cluster of houses on a long thin island across the way, one of thousands on the great river. Back behind the town's houses lie the manioc fields and farinha processing houses, and further beyond are 


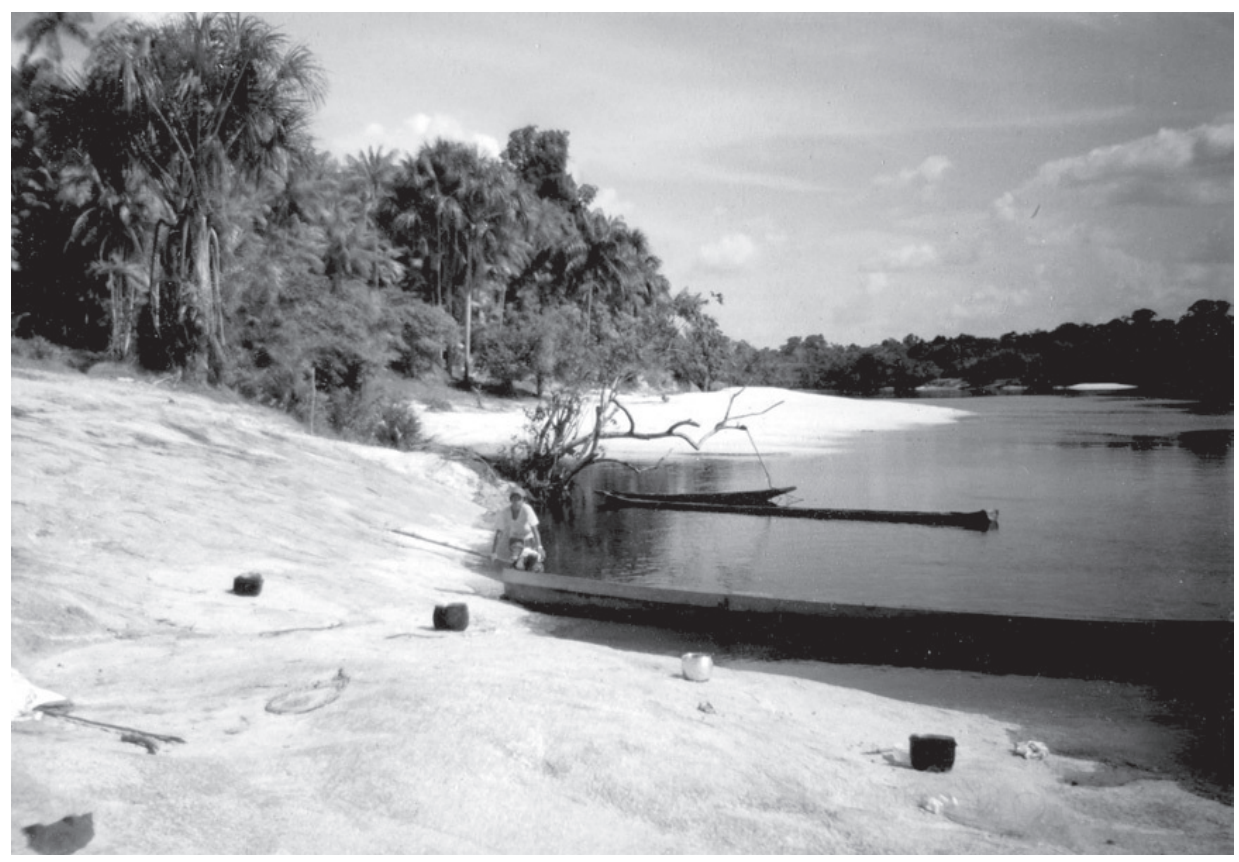

Figure 1 Upriver. The garapá (porto in Portuguese); a granite beach used for mooring canoes, filling water containers, bathing, washing clothes, etc. The beach is a site of cultural contacts and changes; it is the primary point of arrival and departure of people and goods in many Amazonian communities.

the forested hunting lands and the streams and lagoons preferred for fishing. Large boats and barges pass by every day or two, plying the waters north to São Gabriel (Tawa) and south to Santa Isabel (Tapurakwara) and further to Barcelos and finally to the terminus at Manaus and the Amazon confluence. With a relatively major thoroughfare passing at its front door, Castanheiro does not particularly have an air of remoteness, geographical isolation or inaccessibility. The conduits and organizational styles of Brazilian national culture are prominent: in the town there is a school house, a Catholic chapel and a community meeting house with a television and parabolic antenna powered by a generator. Houses spread out on several axes, in parallel and perpendicular lines. Most townsfolk are the relatives of their neighbors; a generation ago Dona Marcilha and her younger siblings, all Tukanos, founded the new community, on the site of an abandoned fazenda, with their spouses and children. Today, most of the town is one extended family.

I arrived in Castanheiro by moving along some of the same family networks ${ }^{3}$; after beginning linguistic investigations with speakers of lingua geral in Manaus, I arranged to visit their home community in order to make some records of how the language was spoken there. This paper is not directly about that linguistic documentation project, but rather draws on conversations I had off camera while getting to know locals and their ways of talking about the world, either in Portuguese or, as time went on, in basic lingua geral. ${ }^{4}$ Some of these conversations challenged my own understandings so thoroughly that I began to keep a running log of them in my field journal, and I cite them here in that mediated state. A few examples of recorded and transcribed discourse will complement those texts to show some of the ways that 
local terms can be theoretical resources for feeling out new approaches to the depolarization of conceptions of indigenous identity.

The people of Castanheiro alternatively identify as caboclos, a term used for mestiços or rural populations with indigenous roots; ${ }^{5}$ ribeirinhos, literally 'river-dwellers'; and indios, or 'Indians.' Indigenous identity often becomes salient in connection with services of the state indigenous organization FUNAI and with the rights to the community lands and waters that make up the Middle Rio Negro Indigenous Reserve that Castanheiro is included in. Other terms and identities can become prominent in different times and spaces blurring fixed distinctions among them; a few community members do not identify as Indians at all, although their spouses and children might. Further upriver and deeper into the jungle are the Vaupés and Yanomami areas where more 'tribal' or 'traditional' indigenous groups reside. Middle Rio Negro peoples can move in an ambiguous area between indigenous and rural caboclo identifications. Legally recognized as Indians but often considered 'civilized' or 'acculturated' when compared to other groups in the area, the people of Castanheiro can variably or simultaneously be indios, caboclos or simply brasileiros.

Literature on the Brazilian Amazon reflects a traditional focus on its indigenous peoples, beginning with colonial accounts and the 19th century explorers' tales, leading to early 20th century ethnographic studies like those of Levi-Strauss, and continuing to be an area of emphasis today, including a sub-focus on cultural change and acculturation (e.g. Caspar, [1957] 1976; Baldus, [1964] 1976; Oliveira, 1974; Galvão, 1976, 1979). In another body of literature, which developed later in the 20th century around the work of Charles Wagley, scholars undertook the study of other sectors of the Amazon population, the mixture of 'acculturated' Indians, mestiços, and nordeste immigrants sometimes referred to generally as caboclos. Wagley, who started his work in Brazil as an ethnographer of indigenous groups like the Tapirapé Indians (Wagley, [1943] 1976), later shifted his focus and called for research on a previously neglected population, those living in the larger towns on the wider rivers who spoke rural Portuguese or Tupí and who often interacted with agents of the Brazilian national society (Wagley, [1953] 1964, 1974; Watson, 1953). Other writers, including several students of Wagley, have offered a number of studies of peasants in different regions of the Amazon (Moran, 1974; Anderson, 1985; Parker, 1985a, 1985b; Weinstein, 1985; Wesche, 1985; Nugent, 1993, 2002). These studies address issues of cultural change and inter-group contact in diverse terms, including ecological relationships, material culture, attitudes and outlooks, folklore traditions and more. Generally the caboclo population is framed as sharing some features with the coastal Brazilian mainstream as well as with the groups of the Amazon interior.

Since the pioneering work of anthropologists working in the Brazilian interior such as Levi-Strauss, ${ }^{6}$ Darcy Ribeiro, Eduardo Galvão, Charles Wagley and others, many different authors have offered different accounts of cultural change. Earlier studies often employed evolutionary terms, tracing a linear movement from more tribal to more acculturated. More recent research in Amazonian populations has led some ethnographers to perspectives that acknowledge the complex multidimensionality though which traditions remain important even as their meanings shift, and where processes of cultural change and of cultural transmission and reproduction are 
undergone simultaneously. Several writers have noted processes in which traditional discourse forms such as shamanic speech are becoming integrated with new ways that indigenous leadership is articulated, an aspect of the ways that 'tradition' is being refigured and reworked dynamically (Oakdale, 2004; Ruedas, 2002). A number of studies have described indigenous peoples' encounters with new technologies and the ways their expressive forms have inhabited the new mediums (Pace, 1993; Turner, 2002). Some have focused on basic epistemological encounters, such as a case describing one indigenous group's first meetings with representatives of the Brazilian state, where confusion grew out of understandings 'based on deep-rooted ontological assumptions and on historical dreaming experiences, crystallized in narratives and represented in rituals' (Fausto, 2002, p. 685). These innovative studies show a few ways for using the methodological advantage of looking to Amazonian forms of understanding for orientation to the problems they address.

The cultural processes of being, not being, becoming or re-becoming Indian operate in spaces where identities can be both more focused or more diffused (LePage \& Tabouret-Keller, 1985). A resurgence of indigenous self-identification has swelled the census numbers of the total count of Brazilian Indians, especially among peoples of the densely populated eastern coast (Oliveira, 2004; Warren, 2001). One anthropologist tells of how a doctor from the state health service tried to enlist her expert input in identifying urban Guaraní people in the São Paulo area, many of whom speak primarily Portuguese; 'since now that they don't go around naked anymore, or wear feathers, it's hard to tell' (Ferreira et al., 2002, p. 130). Another writer describes how in a certain community there was a surge of Indian identity soon after a visiting anthropologist made the observation that the local culture had many indigenous features (Barretto Filho, 2004, p. 132). Populations can be considered indio or caboclo at different moments by different actors, crossing these boundaries throughout their history (Oliveira, 1999). While the term caboclo is generally associated with indigenousness, some people have rejected generic indigenousness, opting for named ethnicities, looking into their community histories to resuscitate old denominations for new purposes (French, 2004). The opposite process is also ongoing and simultaneous in other parts of the Amazon, where 'ex-indigenous' is an emerging identity (Gow, 2003). In one area of the Peruvian Amazon, Gow (1991) describes people who frequently move between self-identifications and who do not find categories like 'mixed' and 'indigenous' to be in necessary contradiction. He suggests abandoning the traditional/acculturated paradox altogether (p. 3) and anchoring our understanding firmly in how people talk about these subjects and in the ways in which native discourses establish truth value. Enmeshed in these negotiations, the social sciences are also confronting their history, watching an old narrative of Amazonian societies dissolve before them, and looking for ways to construct something in its place.

Meanwhile new methodologies offered by the biological sciences such as genetics have opened up innovative and sometimes unsettling possibilities. For example, one study entitled 'Ethnic admixture contributions of two Amazonian populations' (Ferreira et al., 2002) uses genetic sampling to show how two 'trihybrid populations' break down into percentages of African, Amerindian and Caucasoid populations: 21 per cent African, 44 per cent Amerindian and 35 per cent Caucasoid in one 
population; 25 per cent African, 12 per cent Amerindian and 63 per cent Caucasoid in the other. Different from the charts that Charles Wagley made in the 1950s, mapping racial categories like branco ('white'), moreno ('brown'), caboclo and preto ('black') onto class positions and gender identity (Wagley, [1953] 1964, p. 132), these categories are not to be considered social constructions, but rather claim a grounding in biological science. Should this information be taken as purely biological data, or is it culturally meaningful in some way? The kinds of correlations that are to be found between ethnographic and genetic studies have yet to be clearly defined at this emergent moment. The terms by which cultural changes, re-combinations, adaptations, parallelisms and pressures can be described are social, biological, technological, material, spiritual and geographical, sometimes yielding exact percentages, but more often revealing ambiguities that defy description and resist quantification.

\section{Topographies of Truth}

Where are can we look today for alternative frameworks for talking about cultural change? In methodological terms, a good way for considering the different cultural elements in modern Amazonian populations in qualitative terms is looking to patterns of discourse ${ }^{7}$ and cultural expression for descriptive and interpretive resources, like the concepts of gradient truth value applied to 'superstition' by Teresinha, cited earlier. Non-Amazonian observers have often referred to the indigenous elements of rural Amazonian culture in terms of the supernatural, making epistemological contrasts. Attending to local ways of speaking about what might be considered supernatural events is a strategy for accessing some of the ways that rural Amazonians like the people of Castanheiro establish the truth value of what outsiders might call the magical or supernatural. Chernela and Pinho (2004) describe talk as the primary means by which a 'supernatural landscape' is constructed and maintained in a Portuguese-speaking rural Amazonian town, where people use some of the same historical, genealogical and geographic anchors found on the Rio Negro to discursively negotiate truth value. ${ }^{8}$

Stories by lingua geral speakers on the Rio Negro share many themes with those of the neighboring upstream Tukano and Arawak groups, ${ }^{9}$ as well as with the Tupian and Portuguese traditions from downstream. There is a wide circulation of story forms and ways of telling that are cross-linguistically pervasive in the region, revealing current and historical inter-group networks and commerce. Dona Marcilha, one of the founders of the community of Castanheiro, related many stories that she had learned from her parents and grandparents, some of which she translated from the original Tukano that she had heard them in. In the following transcription excerpt from a recording of Dona Marcilha telling a story to some of her children, the participants made it explicit that I was to understand the story as true information, as validated through a connection to a family member's experiential connection with the geographical location of the story.

Storyteller: Suasú yuruparí raíra paá.

The deer is the child of a devil, they say. 
Iyusana tem paá kwaá iwitera, Serra Neblina tanheé waá.

His trap is up in these mountains, they say, the ones called Serra Neblina.

Suasú, a-kití paá umunhá iyusana.

The (story of) deer; up there (the devil) made a trap, they say,

Nhaá kunhá resé paá enamorari paá, mira retewa resé nhaá yuruparí in order to seduce women, to seduce real people, that devil, they say.

Asuí paá kwaá hora paá usu-ã paá nhaá yurupari.

Later, they say, at that time, they say he went, that devil, they say...

Son:

Yuruparí wasú.

The big devil.

Storyteller:

Yurupari usú-ã.

The devil went.

Daughter:

Renheé xupé kwaá paá historia retewa.

Tell him that this is a true story, they say.

Storyteller:

Kwaá historia retewa, katú - (?) seremiarirú aé paá usú.

This is a true story, it's good - (?) my grandson, he went there, he said.

Marcilha tells us that her grandson has been all the way to the Serra Neblina, the home of the yurupari, and has confirmed the truthfulness of the events in the story with linkages to the local landscape. Note the use of the evidential reportive marker paá (underlined), about once per line, a way of negotiating and sharing orally

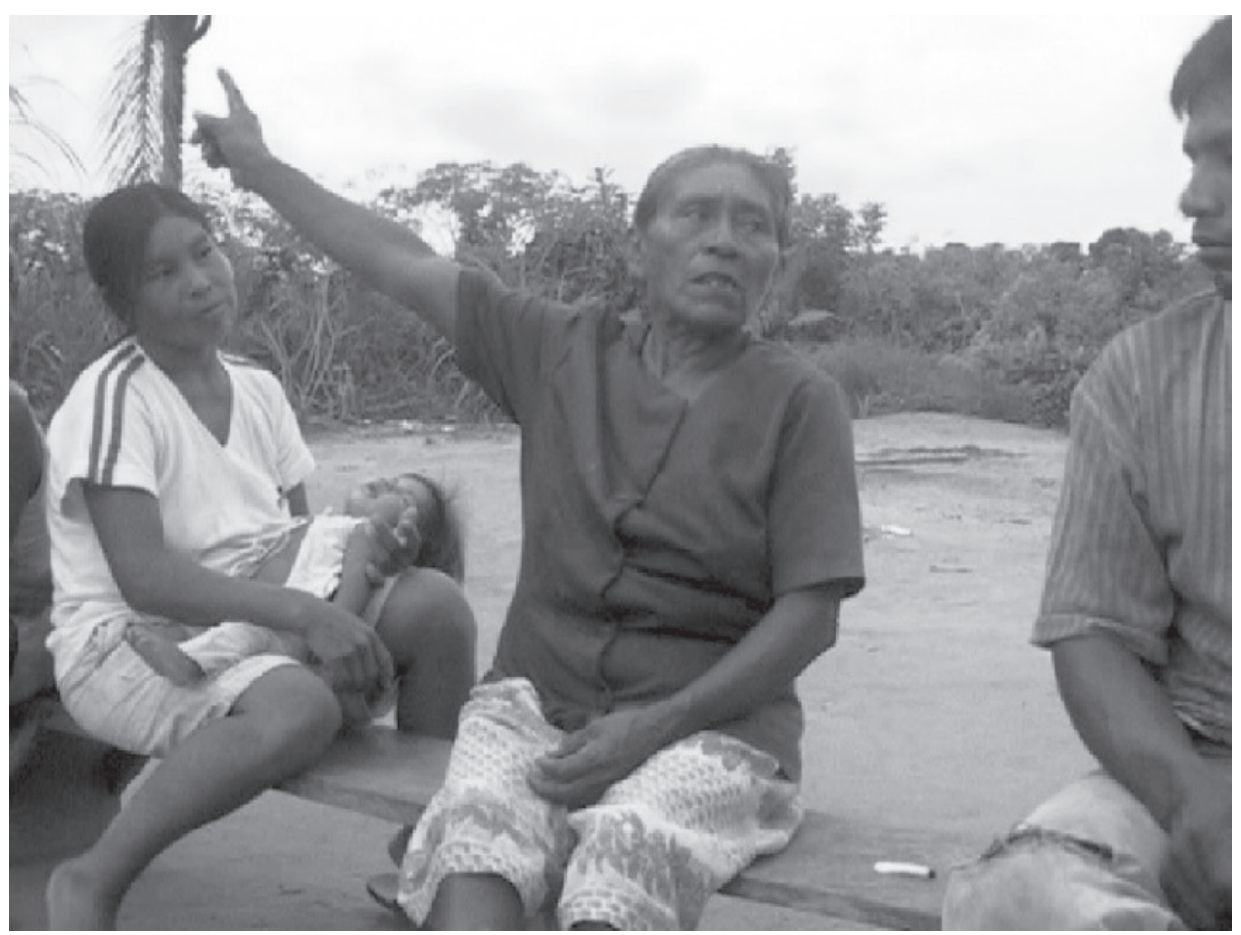

Figure 2 Dona Marcilha traces the veracity of her story over the geographical landscape. She is pointing to the Northwest, where the Serra Neblina rises out of the Rio Negro plains. 
transmitted information (I offer an approximate translation as 'they say'). ${ }^{10}$ The Serra Neblina is a distant mountain range on the Venezuelan border to the north, whose foothills are just visible on a clear day from the Rio Negro. The mountains are home to Yanomami peoples who, for some Rio Negro locals, inhabit an extreme of traditional forest culture, are sometimes referred to as 'unbaptized,' and are known for their powerful shamans. It is in that far-off place that Dona Marcilha situates her story.

The exchange in the last few lines of the transcript above shows how geographical and genealogical elements are involved in establishing the truth value of a story about 'supernatural' beings. The storyteller and her daughter orient around into these tangible elements to make sure that I, the kariwa (white person), properly understand the story as retewa, or 'true.' The reality of traditional knowledge is tied into real experiences of space, history and family.

When British naturalist A. R. Wallace, a contemporary and friend of Darwin, passed Castanheiro in the mid-19th century he found a Portuguese farmer and his family, with whom he stayed for a few days (Wallace, [1889] 1972, pp. 138-139). The graves of these settlers and some of their descendants are all that is left of the European founders of Castanheiro, which appears to have been deserted sometime in the first decades of the 20th century. The town was repopulated mid-century by migrants from upriver places all over the region between the town of São Gabriel da Cachoeira and the Colombian border along the Vaupés and Içana rivers. As they came together as a community and built their new town, they interacted with the new environment there on the shores of an enormously wide stretch of the Rio Negro. Listening to one community member reminisce, I paraphrased his tale of community history in my field notes:

Over to the west of town there used to be an enormous tree near the graves of the Portuguese colonists. Every evening around sunset the people in Castanheiro used to hear some kind of ghost or bicho beating on the tree-trunk, making resounding great THUMPs! One day one of the men had had enough of the sound, so he went and chopped the great tree down and burned it. From then on the noisy bicho never returned.

Apparitions of forest bichos link to the physical and historical places of the gravesites and the old tree. The tree seems to have been a vital habitat for the creature that came to thump on its trunk, and through extracting that sector of forest on the edge of town, one community member was able to send the creature back into the woods. In discourse and experience the fantastic or dangerous inhabitants of the forest are rooted in features of the local ecology. If less such creatures are encountered these days, it may be connected to the fact that there are fewer big trees for them to inhabit, trees that people cut down as they change the nature of their impact on their environment.

\section{From Science to Magic}

The previous sections began to show some ways that Rio Negro people negotiate truth values in a changing world. This section will return to the work of Charles Wagley as a way to put Amazonian ways of talking about social change into 
dialogue with the ways that cultural change in the Amazon have historically been framed in anthropological writing. In the mid-20th century, scholars such Robert Redfield (1960) called for an expansion of the field of study of traditional indigenous subjects to include rural peasantries as culturally distinct, important and interesting groups. The rural populations appeared to be 'in between' the more isolated or traditional groups and the urban mainstream, and some scholars saw people such as the Amazon caboclos as representing a 'way station of Westernization,' as the title of one essay puts it (Watson, 1953), an intermediate stage defined not by what it is, but by what it was and what it is assumed to be becoming. These 'in between' peoples were seen as having no cohesive culture of their own, but as representing a phase in transition between Indian and non-Indian culture. Wagley's Amazon Town has a chapter entitled 'From magic to science' which begins with the passage below:

In our own civilization scientific and naturalistic explanations have gradually replaced magical and supernatural explanations for phenomena and for events. This basic change in our world view began centuries ago and is still taking place with ever increasing velocity. Only a relatively short time ago, rainfall was thought to depend upon the supernatural, and malaria was believed to result from bad air or bad 'humors.' Magical means and prayers were used to ensure sufficient rainfall for the crops. Often harmful precautions, such as sleeping in a room tightly closed to keep out night airs, were used to prevent malaria. Nowadays rainfall is attributed to natural causes and can even be produced by scientifically controlled experiments. Today it is known that the anopheles mosquito transmits malaria; science has shown us how to control the disease through control of the insect. Similar examples might be taken from almost any sphere of our way of life. As the field of science expands, the segment of human experience depending upon magical or even 'common sense' explanation is steadily reduced. ([1953] 1964, p. 215)

Systems of magical causality are seen as being eclipsed by the expanding field of science, which claims more and more of the space that the supernatural once occupied, eventually giving way entirely to a unified scientific system of knowledge. There is no room here for more true and less true; magical causality is strictly untrue and thus will be revealed by the true reasoning of science. This one-way sequential model of changing perspectives is difficult to apply to rural Amazonian systems of knowledge; it is not a very good account of 'our own civilization' either, where battles between creationists and evolutionists is only the most obvious example of the continued tension between different causational logics in United States society.

Practices of circular reversion to old knowledge after exposure to new information, or of parallel adaptations to form combinations of strategies from both Western and indigenous knowledge systems, defy the timeline of acculturation by patterning in spirals and webs instead of straight lines. Wagley notes that some Amazonians were hesitant to spray DDT in their houses and communities to combat malarial mosquitoes, a hesitation that he attributes to a failure to adapt to scientific causality ([1953] 1964, pp. 252-255). Looking back with hindsight it might appear that Amazonians were a step ahead of science, as they seemed to 
sense coming controversies about the poisonous effects that DDT could have on them, their neighbors, and the local environment.

The inverse scenario to indigenous acculturation, that of Western people who hold scientific views of causality adapting to the alternative realities of magic and the supernatural, has also been known to occur, and sometimes in less superficial ways than the obvious example of New Age pilgrims seeking out indigenous spirituality. British ethnographer Evans-Pritchard found that, after immersing himself in the coherent and comprehensive systems of Azande witchcraft, it was possible to simultaneously operate within apparently contradictory systems, 'to say that one lives in two different worlds of thought at the same time, in categories and concepts and values which often cannot be easily reconciled,' resulting in a state of ambiguous 'half-believing' ([1937] 1976, pp. 243-244).

The experience of 'half-believing' that Evans-Pritchard felt when he found himself living and acting in accordance to the logic of magic is similar to that of Teresinha from Castanheiro, who organizes cultural practices in grey areas of less true and more true. The synchronic dual validity of multiple systems constituted by webs of gradient truths destabilizes unidirectional models of acculturation that associate indigenous perspectives with the waning past and Western perspectives with the oncoming future, banishing Amazonian peoples into earlier stages of history. Another passage by Wagley directly equated modern processes of change in the Amazon with the historical change of Europeans, effectively placing rural Amazonians at an earlier temporal location:

The world view of the people of Itá and other Amazon communities is in a process of transition. The change from a magical folk to one which possesses a modern scientific view of the world is one that took place some time ago in many centers of Western Civilization. It is still taking place in many out-of-the-way regions of the Western World. The process has reached a point in Itá equivalent to that reached in most Western communities many years ago. ([1953] 1964, p. 252)

Figure 3 is a visual representation of the scenario described in the passage above, with caboclos from communities like Wagley's pseudonymous town Itá or the real community of Castanheiro trapped in the European past, rather than in a parallel, current alignment with modern Western civilization. Figure 4 presents a copy of a similar drawing found in a 1980 collection of anthropological articles on acculturation that brings the timeline out in its most explicit form. ${ }^{11}$

While Wagley is perceptive in pointing out ways that rural Amazonian people interact with forces and beings that holders of the 'modern scientific view' would consider supernatural, he characterizes the caboclo as existing out of the present moment, in a stage that modern societies have long left behind, and pushing cultural forms into an orderly spot on the line. A better approach might have taken into account the fact that magic can be just as contemporary as science and that in many ways it operates according to reasonable, logical principles. I will sketch some of the ways people talk about interactions with shamans, or pajés, and encounters with supernatural beings and forces. Instead of necessarily being erased by a 'modern scientific view,' Amazonian thought finds ways to coexist with it or sometimes to counter it. 


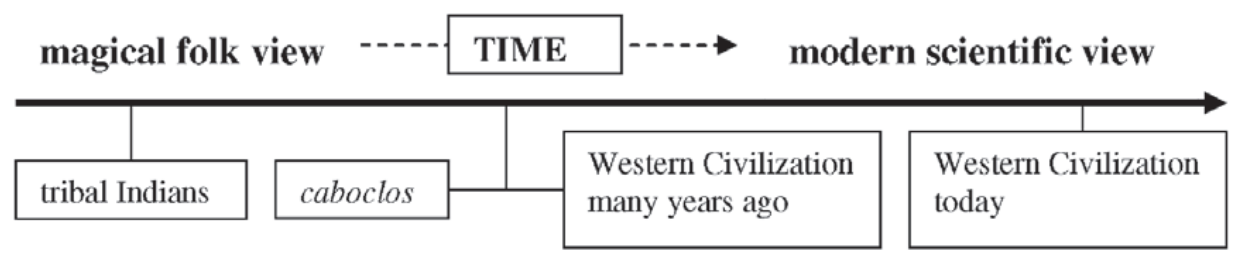

Figure 3 A graphic representation of the epistemological location of Amazonian caboclos with respect to Western civilization past and future, as described in 'From magic to science' in Wagley's Amazon Town ([1953] 1964).

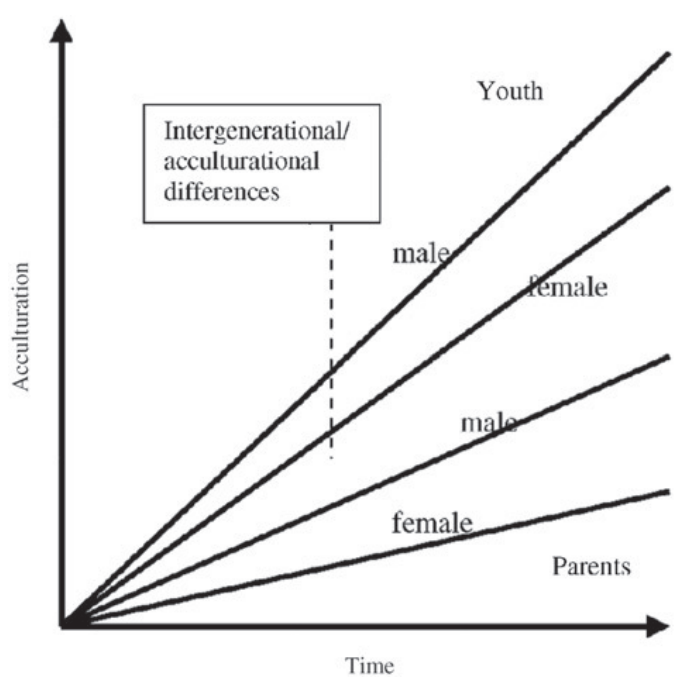

Figure 4 A theoretical model of acculturation as linear movement over time. Graphs adapted from Acculturation: Theory, Models and Some New Findings (Szapocznik \& Kurtines, 1980, p. 146).

If it is true that the power of the pajés is less overt now than in the past, it is not because the locals, in their encounter with science, have begun to believe that there is no such thing as shamanic power; instead it is because people are forgetting the old skills. The knowledge of the paje is from earlier times, from the times when people spoke Tukano, Piratapuya, Baniwa, Tuyuka, Baré, and a dozen other languages. People in Castanheiro know that one cannot sing a blessing in Nheengatú, only in whispered Tukano, left as the last evidence of the grandmother tongue. Lingua geral does not wield the same magical force, and socio-linguistic changes such as language shift intermesh with shifting fields of knowledge and power. The pajés are not as strong now as they once were; they are losing all of the old words, speaking in geral and in Portuguese.

The power of the pajés, although it may have diminished, is at present a vital defense against the hazards of jungle life. In the early days of the Amazon gold rush, when Dona Marcilha's brother Luis spent months at a time deep in the bush, he had a number of close encounters with powerful beings of the forest. In the account below, recorded in lingua geral, Luis meets the infamous curupira, and explains why he was lucky to have a pajé named Joanico for his companion.

Ape ayiri ape usasemu-ã, ape uri iwitú amana e trovão.

Then I turned as he shouted, and then the wind, rain and thunder returned. 
Pituna wasu-ã mirá pedaso-tá uwari.

Nighttime came and tree branches fell.

Waá sasemu, kwaá trovão wirá pã mã-kití, boa sasemu ti kwaíra nhaá.

That shout was like thunder and sent the birds flying, a loud shout - not quiet.

Yawe-rã sewara asiké kurupira-suí.

And like that, I myself arrived where the curupira was.

Kwaá-tá membeka ixe-rã, kwaá-tá ayana varador asú ape kwaá usasemu EEEE!

These (knees) went soft on me; I ran for the path and here, it shouted EEEE!
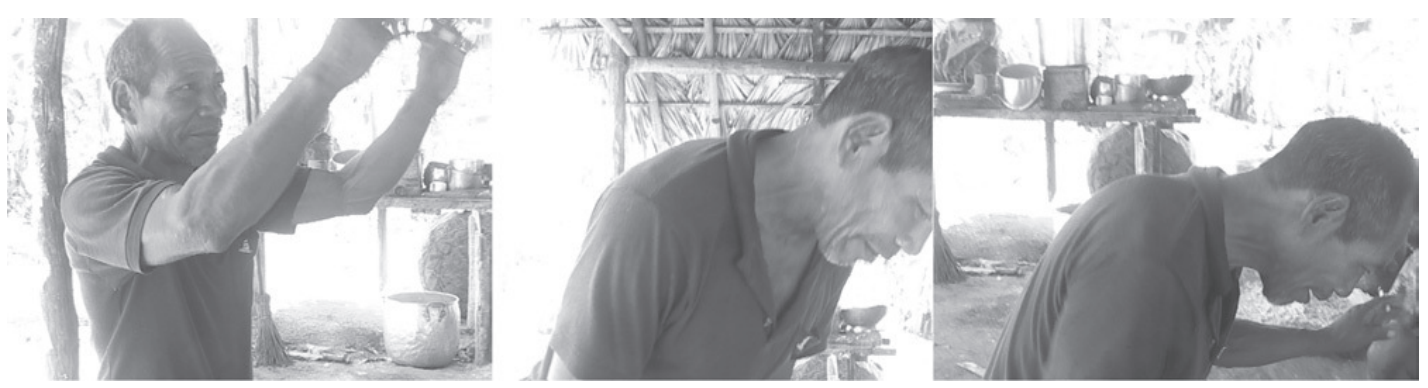

Figure 5 Luis performs his physical reaction to an encounter with the curupira, first falling as his knees give out and then struggling to stand. He remained weak until later when he was cured by a pajé who blessed him with tobacco smoke.

Porra apunheé apunheé kwera ne umeé. Porra apuamu asú iri.

Damn, I crawled and crawled but I could not find him. Damn, I was able to stand and go.

Aikwé yepé busú iwa-wasú Joanico upuamu,

There was a large palm tree where Joanico was standing.

Joanico ape uiku umunhá uiku jakurawa.

Joanico then was making a 'bird tail' (leaf umbrella).

Ape asú sepira-mirí sepindaíwa awatá-iku maá-kití amburi.

Then I went and as I wandered I threw my little fish and fishing pole wherever.

Ape 'Nhaá kurupira,' anheé xupé. 'Kurupira tinku.'

Then 'It's the curupira,' I said to him. 'The curupira is there.'

Ape amunhá jakurawa.

Then I made a 'bird tail' (leaf umbrella).

Kartuxo-rirú patrona-mirí upeka pã uxari.

(And he got) the little shell casing where he had wrapped up (the tobacco) and left it.

Ape uyuka upirari kartuxo-rirú umunhá cigaro umundeka ufumari.

Then he got it and opened the shell casing, made a cigarette, lit it and smoked it.

Luis felt the physical effects of his curupira encounter until the pajé blessed him with tobacco, the appropriate cure on this occasion. Among Rio Negro peoples, failure to comply with the complex system of hygiene, food and hunting regulations can bring misfortune and attract dangerous creatures such as the curupira monster mentioned above. In the following story of a family fishing trip a generation ago, 
one community member tells of such an instance:

Once when we were on a fishing trip my cousin had her first menstruation but she did not tell anyone. We were camped out on the shore with my dear departed grandfather when all of a sudden a storm blew in and the day became as dark as night. A sound came out of the forest: uuuiiiiiii! 'What did you kids do?' asked our dear departed grandfather. 'Nothing,' we replied. Nobody knew about my cousin. The sound got louder and louder and we heard something moving around in the river, moving towards our camp. We were all scared; finally my cousin told our dear departed grandfather. Quickly he began to bless her, lighting a cigarette and blowing the smoke on her. A great black serpent, about 30 meters long, surfaced in the river and began moving towards our camp, but as soon as dear departed grandfather finished blessing her the storm died down all of a sudden and the serpent disappeared under the water. In a couple more minutes it would have reached us. Dear departed grandfather used to tell us about saruã. 'If I hadn't been here,' he said, 'that bicho would have eaten you all.'

Conditions such as sarua, a kind of sickness or affliction, and panema, a chronic bad luck in hunting and fishing, can be brought about by such unfortunate circumstances. Similar discourses and restrictions can be encountered in many parts of the Amazon; Wagley describes a Portuguese-speaking population of a town in Pará in the 1950s who shared many of the same precautions and wisdoms with the people of Castanheiro. He mentions hunters who, when negotiating these regulations on a hunt, 'do not distinguish between the tangible natural world and the supernatural' (Wagley, [1953] 1964, p. 76). Evil magic or encounters with creatures like curupira are known around the Amazon to create adverse physical and spiritual conditions, reflecting a systematic casual logic attributed to what is difficult not to refer to as 'the supernatural.' As illustrated in the story above, the best way to counter these conditions is with a blessing by a pajé, a traditional doctor/shaman. In the past a good pajé used to be able to bless away nearly any problem; today there are not so many who still retain that old knowledge. For many rural Amazonian people, the distinction between natural and supernatural may not be as salient as the one between remembered and forgotten. The changing relevance of magical danger and the preventive skills of the pajé are expressed in terms of the successful or unsuccessful transmission of a body of knowledge. Local knowledge systems are as valid as they are operational, and can fade from memory as they fade from prominence.

The rural Amazonian's first-hand experience with forces and beings that scientific knowledge cannot or will not easily explain reinforces an alternative Amazonian body of knowledge, one which often corresponds better with the immediacies of forest life. When Amazonians inadvertently attract a dangerous creature like the great black serpent mentioned in the anecdote above, their encounter might contradict a scientific account that denies the serpent's very existence. While in Castanheiro I heard locals scoff about a group of scientists from São Paulo who had brought a television crew to the Rio Negro in search of the region's largest anacondas; the scientists had claimed that the snakes grew up to a maximum of 10 or 12 meters. Any local person who had fished in the lagoons and inlets of the Rio Negro could have seen snakes twice that size with their own eyes, everyone said. Rural Amazonians are experts on their environment in ways that a superficial visit, even if undertaken in a 
scientific framework, cannot approximate, and Amazonians will often trust their own eyes over an outsider's 'scientific' explanation. They might well offer a different account of social change than the one I am presenting here, even as I try to anchor my analysis in local terms.

I remember having an afternoon chat with some of the men of Castanheiro as we watched lightning strikes trace themselves across the sky off to the east. The town schoolteacher pointed to the storm. He said that in the past pajés had often been known to send lightning after their enemies - his words are recorded in my notes as follows:

Lightning contains a stone that shoots like a bullet. You can see its path in the marks that it leaves on the tree-trunks it tears apart. It goes through the tree and then into the ground, leaving a path behind it, going off - who knows where? They say that pajés create thunder and lightning bolts. In the old times they used to send many lightning bolts, but now many of the old pajés who know how to do this have died.

The schoolteacher asked me what my people's explanation for lightning and thunder was. I told him that we say that lightning is electricity generated by turbulent air during storms, that thunder was the sound of the air slapping together, and that lightning could split trees with the heat it generated. Unconvinced, he simply said, 'When you see the tree split in half, you can see where the bullet passed. People from the city have one explanation, people around here have another.' Not explicitly placing my explanation into conflict with his, he clearly found his explanation to be more reasonably grounded in his experience. Neither a pajé nor a meteorologist, I am not sure how well I could ground a contrary argument.

On the Rio Negro both Western medicine and pajé curings are considered complementary alternatives for specific problems. When I developed a sharp pain in my leg Dona Marcilha asked her brother Antenor to say a Tukano blessing for me. They determined that I had the condition known as saruã, which had entered my leg after I swam at the same spot that where a mother had bathed her three-day-old newborn a few hours before. No one was surprised when, the morning after the blessing, the pain was completely gone. Antenor explained that he only knew a few of the old blessings; his Tukano-speaking father had known many more. The powers of the pajes, the force of the old rules and restrictions, the appearances of forest monsters and powerful beings, are all currently operational. Some Amazonians suggest that their power may be waning, but they still keep a wary eye out when they walk in the forest.

In order to address the social changes through which shamanistic powers and dangerous forest monsters are becoming less visible, local people offer perspectives that help inform our judgment about what is 'real' and what is 'supernatural.' Rather than setting up a dichotomy between magic and science, they offer reasonable systematic explanations for the decline of supernatural happenings. The older pajés from far upriver are dying off and the young ones, raised further downriver, are not learning all of the blessings, so they are less powerful today. Wagley describes a similar scenario for people in Itá; the younger shamans are only an echo of an older generation from far upriver who had powerful abilities to speak with spirits and travel underwater wearing snake skins ([1953] 1964, p. 227). In Itá as 


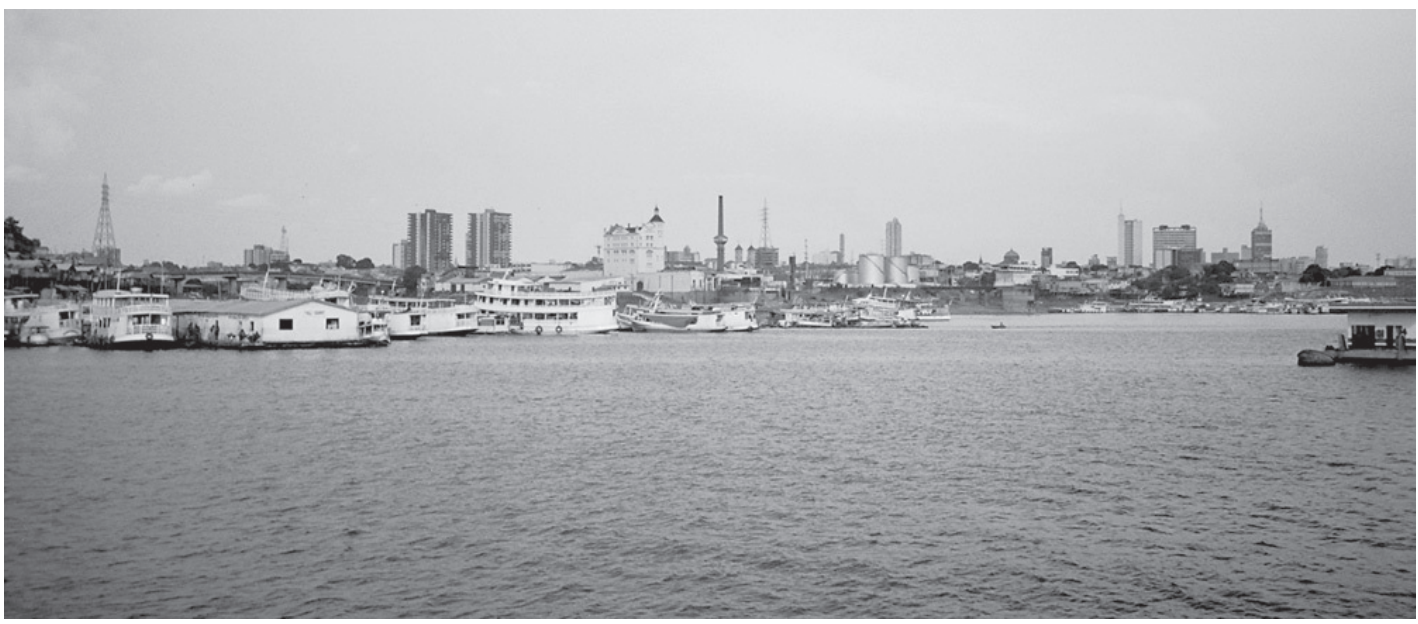

Figure 6 Downriver. The port of Manaus; large ships disembark every Friday and, two or three days later, pass directly in front of the garapá in Castanheiro.

in Castanheiro, the power of the pajés is traced in generational time as well as geographical space. One of the famous Itá shamans that Wagley describes grounded his credibility in the Tukanoan and Arawakan cultures of the upper Rio Negro, the topographical origin of the most potent magic. Downriver migration moves people spatially and temporally away from the upriver extremes, and shamanic powers, magical sub-surface movement and terrible river creatures like the cobra grande become more true or less true depending on different temporal, spatial and social positionalities. At the downriver extreme are the urban ports, Manaus (Figure 6) and Belém, yet even these places are not devoid of magic for those who would continue to make it operational in those contexts; for rural Amazonians these places are real extensions of their own experiential magical worlds - and some visitors have been known to sense the cobra grande swimming below the pavement in the city sewers (Campbell, 1989, pp. 82-83).

\section{Under the Surface}

Boaters on the Rio Negro know that submerged rocks are more dangerous than ones that stick out above the surface, because the latter are more easily spotted and avoided. Explicit hierarchical rankings of cultural groups have been progressively pushed under the surface where they are more difficult to circumnavigate. Assuming that linear models of cultural change are no longer influential in academia, however, ironically attempts to place the social sciences in their own linear trajectory in which outmoded ideas are always progressively replaced by better ones. If the writings of Wagley represent a moment when the chronotope emerges relatively explicitly, the examples I will address in this section show some of the ways the chronotope of cultural change persists in scholarly discourses about Amazonian people in much more covert ways.

Frameworks drawing on the biological sciences like the genetic study cited previously begin to resemble revived evolutionary paradigms even as social 
anthropologists are attempting to deconstruct them. For example, in a recent article entitled 'Blood pressure, seasonal body fat, heart rate, and ecological differences in caboclo populations of the Brazilian Amazon,' the authors make a correlation between high blood pressure and 'modernization' or 'exposure to and participation in Western culture' in caboclo populations that they succinctly describe as 'trihybrid, rural peasant groups who originated from the admixture of European colonizers, Native South Amerindians, and Africans brought as slaves to Brazil' (Silva et al., 2006, p. 11); caboclos are 'admixed' people as compared to 'genetically homogenous traditional indigenous populations' (p. 11). The way that biological data is correlated with cultural change resonates with the acculturation paradigm of the 1950s:

The observed political, economic, sociocultural, subsistence and environmental differences between villages provide a first approximation to their position along the 'traditional-transitional-cosmopolitan' continuum. Caxiuaña residents are not completely traditional in the sense of still practicing life ways that prevailed several generations ago among Native Americans. However, they do practice more of the life ways and economically more resemble such earlier groups than do residents of the other two communities. Conversely, Aracampina and Santana residents have a more varied economy with greater access to wage labor, cash income, consumer goods, and a large local city (Santarím $[s i c]$ ). These community-to-community differences allow us to test for average differences across levels of transition from traditional to cosmopolitan...(2006, p. 13)

The metric that these authors are employing reveal a conception of the nature of cultural change as unidirectional along a 'traditional to cosmopolitan' axis. In another recent article entitled 'Concepts of illness and treatment practice in a caboclo community of the lower Amazon,' Reeve (2000) offers what is for the most part a sensitive account of the interplay between local healing practices and Western medical knowledge. However, the reader may notice that, when reference is made to any of the Amazonian practices, they are always accompanied by the phrases 'are said to' and 'is believed to,' whereas references to Western medicine are associated only with a significant silence. Compare these two sentences with attention to the phrases in italics (my emphasis):

The sun, moon, and wind are conceived of as supernatural forces that can cause illness.

(p. 101)

Disease prevalence in the region is largely a result of poor sanitation and inadequate diet, as well as lack of access to health care facilities. (p. 105)

We can see by comparison with the 'Blood pressure' article cited above that the opposition between magical and scientific practices here is much more deeply submerged, down to the level of marked and unmarked linguistic forms, where it is naturalized. But if on the Amazon, as Reeve says, 'traditional medicine is a salient marker of ethnic identity' (p. 96), then this is no less so anywhere else, and care should be taken when delineating a rigid division between different groups of people and their respective thought systems.

While the literature specifically about caboclo cultures dating back to the era of Wagley often pointed out similarities between caboclos and Indians, it has tended to make concrete the distinction between groups that are not always easily 
distinguishable in practice. ${ }^{12}$ A recent collection of articles entitled Some Other Amazonians (Nugent \& Harris, 2004) deals specifically with Amazonian peoples who are explicitly 'non-indigenous,' but as Green notes, 'at the end of the day the only thing that makes these "Other Amazonians" cohere as a group is the fact they are not Amerindian' (Greene, 2005, p. 460). By solidifying the permeable boundary, once again 'traditional' and 'acculturated' are problematically constructed as discrete categories with no overlap.

The border between indigenousness and non-indigenousness is still heavily policed, and the traffic crossing the border remains decidedly unidirectional in the eyes of many people and institutions. In one case described by Santos \& Oliveira (2003) an anthropologist was sent to assess the claims of a group that was asserting indigenous identity and the corresponding land rights in the face of local politicians and others labeling them opportunistic 'false Indians' (p. 168); the anthropologist spent only a few hours with the people in question before reporting that they had no grounds for claiming indigenousness, surely to the delight of their opponents. Later, a second anthropologist undertook a more serious investigation and found she was able to describe unique local ways of speaking about personhood, group membership and genealogy that, under most definitions, would qualify as elements of indigenous culture, even when spoken in Portuguese by people wearing blue jeans (Santos \& Oliveira, 2003, pp. 15-140).

Contention over contested flows of cultural change and authenticity are sometimes brought to the foreground, as during a recent scandal involving anthropologist and current president of the state indigenous administration FUNAI, Mércio Pereira Gomes, who was quoted in an early 2006 interview as saying that the resurgence of indigenous self-identification was going too far: 'It's too much land,' he said, and pointed out that until now there had been little state regulation of identity-based claims, and that soon the Supreme Court of Brazil should define limits, presumably before the claims began to snowball out of control. For many indigenous people these statements implied something a little too close for comfort to the cliché 'too much land for too few Indians.' Quickly after the interview was publicized, indigenous organizations like the leadership of the Kayapó from the Xingú area registered their displeasure:

President, we indigenous people of the Mebegokre ethnic group are very worried about your declaration in the newspaper where you stated that there is 'too much land for too few Indians.' We did not expect a (FUNAI) president who defends the Indians to say a thing like that. We have heard politicians, hacienda owners, gold miners and land invaders speak against us, but a president should never speak against Indians. (Txucarramãe 2006 Statement, signed by Kayapó leadership; my translation)

Soon indigenous leaders from north, central and southern Amazonia spoke out supporting the Kayapó statements (COAIB, 2006). Indian voices from around Brazil chimed in, including indigenous anthropologist Florencio Vaz, who shared his analysis on the web (Vaz, 2006, posted on www.midiaindependente.org):

'Too much land for too few Indians,' was an argument that we grew up hearing, always on the part of the sectors contrary to the indigenous peoples. Those who enjoyed the stupid comparison of the group of Indigenous Lands (TI) with the size of European 
countries always show how absurd of the Indians it is to have so much land. A chorus of anthropologists argued that the Indians had another mode of life that could not be evaluated by the same criteria used for non-indigenous. But those were other times. And those anthropologists were others. There were few to inexistent indigenous organizations, the Indians themselves did not number above 200,000, and the danger of extinction was real and immanent. Demarcation of the lands would be a way to guarantee the survival of 'primitive' peoples and cultures. The more 'primitive' a people, more reason to demarcate their land. The times went changing... (Vaz, 2006; my translation)

Vaz charges FUNAI with a kind of 'ethnic cleansing' achieved by discounting many of the new self-identified Indians counted in the last census, when increased indigenous numbers upped the stakes for all parties. He also chastises anthropologists for their lack of conviction and for their level of complicity in these processes. Vaz points out how an ideology of purity is being used to de-Indianize all but the most 'primitive' and 'forest-dwelling' people and deflate their identity-based claims. ${ }^{13}$ It is clear that Vaz as well as many other indigenous people have suspicions about granting the state full rights to judge their authenticity, because it severely weakens their political position; the moment their Indian status is revoked, they have no more claim to indigenous rights.

While Mércio Pereira Gomes is an accomplished anthropologist and author of a book-length survey of Brazilian Indians that describes indigenous resurgence as a positive challenge to linear notions of cultural change (Gomes, 1988), for many indigenous people his actions as FUNAI president seemed to contradict this earlier position by threatening to limit re-Indianization movements. Vaz points out some of the contradictions: 'Maybe he would say now, "Forget everything I ever wrote") (Vaz, 2006). At this moment the unidirectional chronology comes back into service in defense of the hierarchies it reflects, and even while it is challenged, it reasserts itself.

\section{'Linguistic' and other Exogamies}

The last section of this paper offers a final example of how Amazonian ways of thinking about genealogy, descent and kinship offer ways to destabilize some of the problematic dichotomies employed in categorizing indigenous identities. In order to illustrate how indigenous cultural elements can remain constant even while simultaneously undergoing change, and how this does not result in necessary contradiction, I will look to some specific social transformations that the community of Castanheiro is currently undergoing with respect to marriage patterns. Upper Rio Negro Indians, particularly the groups of the Vaupés, have been described as featuring a system of 'linguistic exogamy' by which, expressed in a simplified form, is meant that marriage partners are chosen from those who speak a different mother tongue. Actually part of a complex system of affinities and inter-group contact, linguistic contrast has traditionally been a major correlate to the pairing of spouses in the Vaupés; the system is described in Sorenson (1967), Jackson (1983) and more recently in Stenzel (2005). Further north in the Rio Içana area the Baniwa peoples are described as having a exogamous clan or sib groups who speak related dialects of Baniwa, while the Nadahup ('Makú') groups from the forest are 
relatively endogamous. In Castanheiro representatives of Vaupés, Içana and other Rio Negro area groups have formed a community together, bringing their different marriage patterns with them. Linguistically the community of Castanheiro today is more or less bilingual, with an older generation of lingua geral speakers, some of whom speak Portuguese as well, and a younger generation of Portuguese speakers, some of whom understand lingua geral. In this new linguistic context, does the concept of 'linguistic exogamy' still have any meaning? Or to put it another way, was linguistic contrast fundamental to the system, or were more deeply underlying norms and practices implied?

People in Castanheiro are conscious of their ethnic group, a category known as etnia. FUNAI registers an etnia for each officially indigenous person. In Castanheiro many different etnias are represented, including Tukano, Piratapuya, Baniwa, Baré, Tuyuka and, for those without an etnia, the non-indigenous category of 'cruzado.' Generally one's etnia corresponds to the language that one's partilineal ancestors spoke, being a feature transmitted from the father's side. Although local people now speak lingua geral and Portuguese, their ethnic family language, which they do not actively speak, continues to be significant.

One afternoon in the community meeting house I conversed with some of the older men of Castanheiro about local patterns for choosing spouses. With their help, and through their discourse, I made a record of several generations of marriages, not one of which represented a pairing of two individuals from the same etnia. Each member of the community had an etnia that was known by the others, and marriage patterns seemed to be obeying a system of exogamy that was not based on the language that an individual speaks, but on the heritage language group of his or her lineage. Since etnia is transmitted from the father's side, a child need not have two indigenous parents in order to have an indigenous etnia; if the father has one, the son or daughter will have the same one. Indigenous women, however, who marry outside of a lineage, cannot give their indigenous etnia to their children.

What emerged from my conversation with some of the elders of Castanheiro was the outline of a system that was both a version of a traditional 'linguistic' exogamy system and an adaptation in response to cultural and linguistic change. What it is not is a replication of a European system of exogamy in which incest taboos apply only to relationships between siblings, first cousins, or parents and children. The men assured me that it would be considered undesirable for two individuals of the same etnia to marry, and the couplings in Castanheiro confirmed their claim, as not one pairing between two individuals of the same etnia can be found in the entire community.

Looking at the top of the chart in Figure 7, the first couple is Dona Marcilha's grandparents, a Desana male and a woman whose etnia was unknown to my interlocutors, as it did not carry on to the next generation. The earlier marriages took place in upriver communities; Dona Marcilha's children and her nieces and nephews were the first generation to marry in Castanheiro. To the left side of the diagram the Desana etnia is shown to be transmitted through two further generations of male children. All of the female descendants of the first couple in this record, shown towards the center of the diagram, had children of non-Desana etnias, as they were 


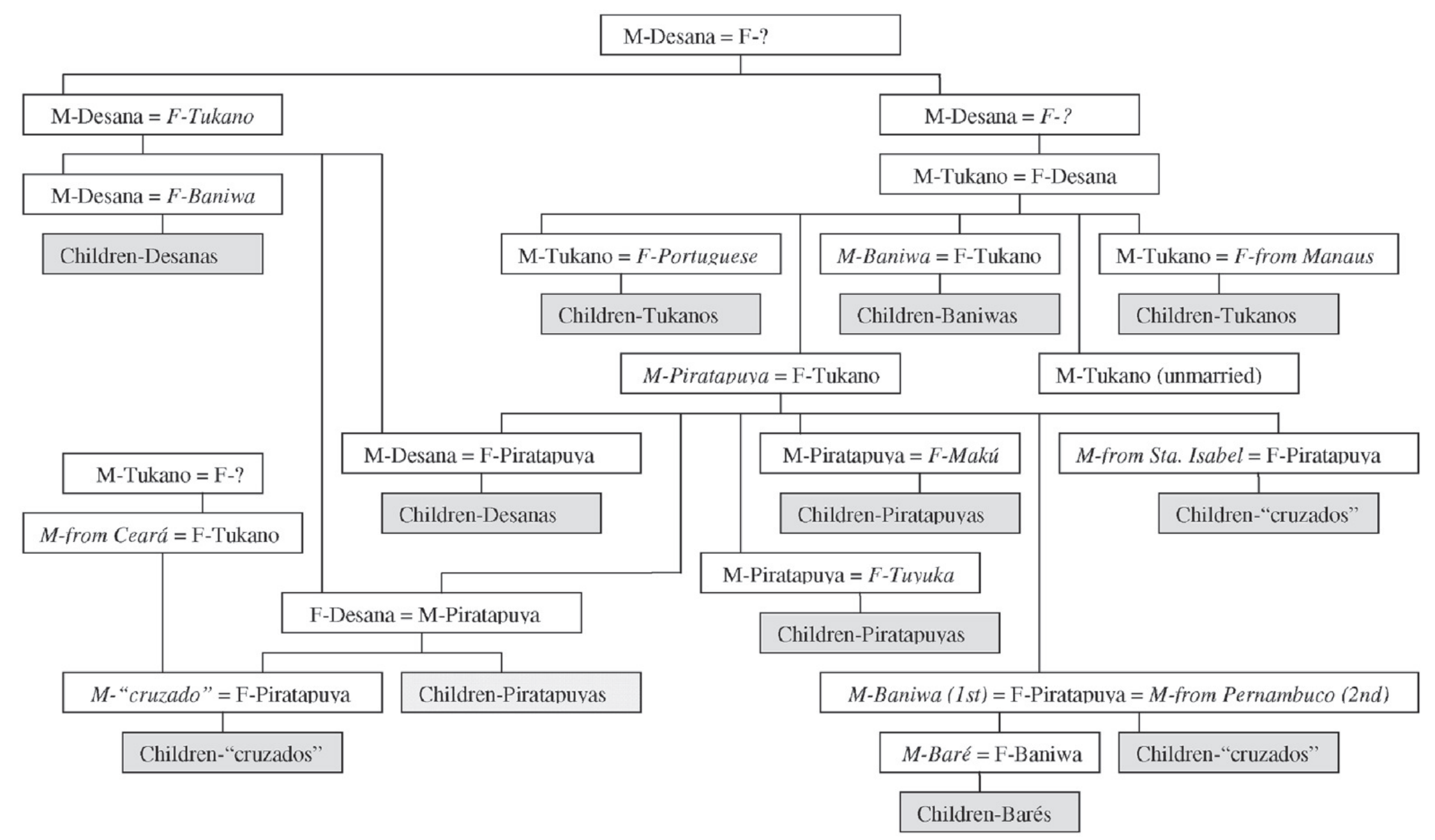

Figure 7 Genealogy of the Middle Rio Negro community of Castanheiro. Each couple is marked with $\mathrm{M}=$ male and $\mathrm{F}=$ female. Individuals who married into the lineage are indicated with italics. An individual cannot marry another individual of the same etnia. Children are assigned their father's etnia. Children of males without an indigenous etnia are known as 'cruzados' or 'crossed.' 
required to marry out of their father's Desana etnia. Other upper Rio Negro etnias such as Baniwa, Tukano and Piratapuya entered into the system as males from other communities married into the family. These unions produced children of different etnias, the men transmitting their etnia and the women raising children of their spouse's etnia. Interestingly, groups not usually included in the system of linguistic exogamy, such as one 'Makú' woman and a number of non-indigenous people, married members of the family and were incorporated into the system. In the case of the 'Makú,' as she was the wife of the pair, the children were considered Piratapuya like their father. In the cases of the non-indigenous people, some of them were the male of the pairing, and according to the principle of patrilineal etnia transmission, their children received no indigenous etnia; they were considered 'cruzados,' 'crossed' or 'half-blood.' It is important to note, however, that these children are not considered 'mixed' in a strictly racial sense, since the girls, when they are grown, are fully able to marry back into the system by choosing an indigenous spouse, at which point the third generation will once again have indigenous etnias.

Given a changing cultural climate where the older situation of multilingual exogamous practices has shifted in favor of a situation of bilingual interaction in lingua geral and Portuguese, and where spouses may be chosen from outside of the traditional marriage preferences, a linear model of change might locate the practices of rural Amazonians like the people of Castanheiro on an inevitable path towards a system identical to that of urban or non-indigenous Brazilians. But the marriage patterns of Castanheiro show a different kind of change, one in which people are actively maintaining a complex traditional system and adapting it to new linguistic and social conditions. In this sense exogamy in Castanheiro is both similar to and different from the patterns described for upper Rio Negro people, and, in a way, it is possible to practice 'linguistic' exogamy without multilingualism. It may be that inter-group exogamy is an independent and underlying cultural feature that only happens to sometimes overlap with multilingualism, so that modern practices constitute a deep form of continuity.

The people of Castanhiero conceive of indigenousness primarily not in racial, ethnic or genetic terms, but instead in terms of native understandings of genealogy. The way that family lines can weave in and out of indigenousness along pathways of patrilineal descent across generations offers a non-linear basis for identity formation that is grounded in local understandings. And furthermore, this way of understanding identity is dynamic, adaptive and extremely resilient over time, and persists in the midst of cultural change.

\section{Conclusions}

By wading through these Amazonian images and expressions, graphs and charts, ethnographic notes and other details, I hope to have presented a clearer view of the complicated nature of cultural change, maintenance, adaptation and transformation among rural Amazonians. I have attempted to put local discourses and cultural patterns into play with the kind of linear unidirectional trajectory of acculturation 
observable in different moments of popular and academic discourse, and to show how Amazonian thought offers resources for reworking it.

In the examples in this essay I described how people in Castanheiro negotiate spatial, temporal and genealogical topographies in order to navigate eddies, currents and whirlpools between upriver and downriver in ways that do not align the world in contradictory binaries. I drew on the non-oppositional epistemology reflected in Teresinha's account of the upper Rio Negro systems of taboos and regulations in processes of becoming less true through changing times. Other community members expressed how genealogical and geographical configurations are a basis for negotiating the validity of information. Some tell how encounters with shamanic power and supernatural beings remain relevant, and how their adverse effects are dealt with on Amazonian terms. The people of Castanheiro offer alternative positions on causality, like the community member who contrasted his understanding of the magical causes of lightning with my schoolbook explanation. I described how many people on the Rio Negro, when speaking about the powers of the pajés, attributed fading magic powers not to their exposure as 'superstition,' but to a failure of young people to learn the old blessings, placing shamanic power not in an opposition between magic and science but in the less delineated realm of the remembered and the forgotten. And finally I pointed out how marriage practices in Castanheiro show that a traditional system of exogamy has remained current as a key site of identity construction through adaptation and reinvention. These examples demonstrate how people in Castanheiro share a coherent epistemological position from which they approach social change along this particular stretch of the Rio Negro.

Rather than patterning in a linear movement over time, cultural change in rural Amazonia moves through a series of spirals, loops, parallelisms and branching multiplicities resting in local conceptions of topography, knowledge, causality, experience, kinship, tradition and innovation. Through my review of Amazonianist ethnography I showed how early attempts to describe this multiplicity and fluidity tried to compress it into a linear timeline, placing Amazonian people closer to the 'primitive' pole. And I described how current Amazonianist ethnography is simultaneously grasping for innovative approaches while sometimes resurrecting old linearities in hidden ways, employing modified versions of the savage/civilized dichotomy and attempting to solidify the boundary between a reified 'non-Amerindian' sector of Amazonian society and Indian cultures. Disjuncture often arises between academic and administrative stances towards indigenous peoples, especially when resources are at stake, and anthropologists working in administrative capacity can find themselves lapsing back into linearity under the strain. I was able to touch on just a few of the many ways in which a binary linear understanding of cultural change persists in submerged forms.

Through their discourse, the people of Castanheiro offer current and operational terms for negotiating these changing times. Not only do their terms prove more agile in an Amazonian context for dealing with contradiction and ambiguity than do most theoretical approaches to social change, ideas such as gradient truth values and genealogically- and geographically-based ways of knowing resonate with some of the most important themes found in social theory and cultural analysis. And specifically 


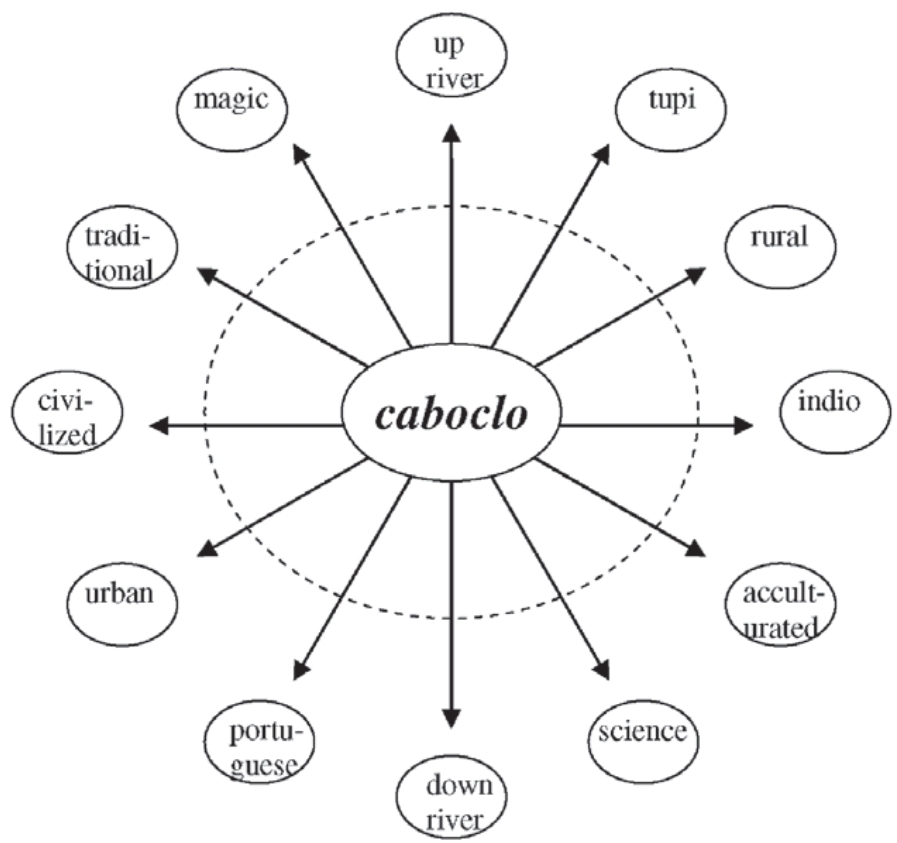

Figure 8 An alternative model of cultural change in the Amazon. The dotted line represents possible positionalities; any point along the line may be simultaneously occupied together with any imaginable number of other possible points in a synchronic and/or diachronic manner.

for the case of the Brazilian Amazon, local concepts about cultural continuity enmeshed in cultural change offer grounds for counterarguments to the challenges to Indian claims of rights and resources that attempt to undermine their cultural authenticity. The ambiguous and dynamic nature of identity in rural Amazonia has presented a constant challenge to attempts to categorize it in bureaucratic statistics and graphs; an individual might simultaneously occupy any given number of points on the graph at any given time, moving forward and backward or upward and downward on the axes. These points are not really graphable, as they are constructed in real action and interaction through performance, discourse and expression. Are people in Castanheiro Indians or caboclos? Are they believers in magic or in science? Are they traditional or modern? The answer is, of course, all of the above, in different configurations in different times and places.

\section{Acknowledgements}

I would like to thank the residents of Castanheiro for putting up with me, my video camera and my rudimentary lingua geral during the time I spent in their community. I particularly wish to thank Dona Marcilha Brazão and her family for their patience, their willingness to converse with me and to help me document local discourse forms, and their excellent fish and pepper soups with manioc. I also must thank Ana Carla Bruno and her family in Manaus, without whom I would have been hopelessly lost in the Amazon. Many thanks also to Pattie Epps, Ben Feinberg, Michelle Wibbelsman, Joanne Rappaport, and two anonymous reviewers for good suggestions and comments. All mischaracterizations and confusions are the result of magical afflictions 
I contracted in the forest from the deadly curupira, as well as of my own ignorance and limitations.

\section{Notes}

[1] Palmie describes the continuing relevance of magic in 21st century Cuba as another counterexample to the unidirectional flow of cultural change, one that helps us to consider the ways in which we can think of 'Western modernity as a configuration of thought and practices that might profitably be understood as culturally specific - if nowadays globally diffused and locally multiply refracted - tradition in its own right' (2002, p. 16).

[2] See Taylor (1985) and Moore et al. (1994) for more on língua geral, also known as nheengatú. It has often been mischaracterized in the literature as a creolized or 'mixed' language. Lingua geral is a Tupian language that has undergone many processes of change, but its basic lexicon, morphosyntax, phonology and discourse forms are typologically Tupi/Amazonian, including features like serial verb constructions, no tense marking, inalienably possessed nouns, an evidential system, etc.

[3] I was in Manaus to support descriptive linguistic programs at the regional level, working with Ana Carla Bruno, a Carib language specialist at a research institute where we organized workshops on methodology and recording technology. Through Ana Carla I met her husband Aldeván's family who are speakers of lingua geral. During a two-month field trip to the Rio Negro community of Castanheiro, I lived in the home of Aldeván's aunt Dona Marcilha. I visited several other towns in the area before returning to Manaus where I continued working with urban lingua geral speakers.

[4] Naturalist A. R. Wallace, in his 19th century account, called the language 'simple and euphonious' ([1889] 1972, p. 334). However, the languages' initial accessibility can prove deceptive.

[5] Pace (1997) questions the use of the term caboclo, noting that it can be offensive and is seldom used for self-identification. While this is partly true, I use the term to reflect the way I encountered it in Amazonian discourse, where I heard it used both to refer to self as well as to others.

[6] Tristes Tropiques offers its own account of cultural change in South America, a search for successively less acculturated Indians; yet once a 'true Indian' thought system is found, it is quickly dismissed: 'The natives are deluded by the logic of their system, but are they not also deluded in another way too? When all is said and done, I cannot help feeling that the dazzling metaphysical dance I witnessed is little more than a sinister farce' (Levi-Strauss, [1955] 1992, p. 244). The same might be said about certain structuralist paradigms.

[7] The term 'discourse' can be employed in many ways. The way I am using it here reflects an approach that sees the properties of language as mutually constitutive of cultural patterns and forms as they are lived through social interaction (Sherzer, 1987; Urban, 1991). The performative nature of cultural identity is shown by 'the recognition that social and cultural categories are not static and monolithic but dynamic and constantly emerging' so that 'the worlds of the people we study are not made up of monolithic abstractions, but rather actual moments and instances of discourse' (Sherzer, 1990, p. 8). Attention to expressive form underlies the way that I approach epistemological systems through performance; even the genealogical information presented here should be thought of as primarily discursive.

[8] Although my fieldwork with Rio Negro people has not been as long-term as my experience in other indigenous South American communities (in Andean and Amazonian communities since 2001, primarily in Ecuador), it was in many ways the most discursively intense field experience I have had. Daily life in Castanheiro is characterized by constant talk, especially during meal times, when everyone gathered to share in conversations, stories, jokes, political discussions and many other kinds of discourse. 
[9] Aikhenvald (1999) shows some similar Tariana stories, many of which have Tukano and Tupi versions in a Missão Salesiana (1961) text collection; lingua geral versions of widespread stories can be found in Amorim ([1926] 1987); also see Saake ([1958] 1976) for a study of common regional story themes among the Baniwa.

[10] For contrast, compare with Luis' curupira story (cited later in this paper); he personally encountered the forest creature, and his statements are unmarked by the reportive. While it is not within the scope of this paper to elaborate on grammatically marked epistemology, the general point is that discursive epistemic stances exist as interwoven through grammatical systems of experience negotiation. See Floyd (2005) for a discussion of evidential marking and indigenous discourse genres.

[11] The papers in the volume are in response to the perceived problem of acculturation of Spanish-speaking groups in the United States, whose distinctive cultural patterns seemed to be an obstacle for their full incorporation into American society. Many of the problems of poverty and discrimination that these groups face were causally attributed to their failure to acculturate; this would seem to get it backwards.

[12] Many caboclo studies point out how indigenous Amazonians have attracted the greatest share of interest in the ethnographic literature. However, enough caboclo studies have been written to justify a recent review article of four book-length monographs on the topic released over less than a decade (Schmink, 2003).

[13] Vaz (2006) continues by pointing out how colonialism and evangelization fostered 'generic' Indian identity for 'civilized' Indians; many of them came to be considered 'caboclos' and face many obstacles if they wish to re-identify as Indians today. He points out how official policy eventually prohibited even lingua geral - after the Cabanagem revolt in the 19th century it was targeted as an unruly indigenous element. A recent New York Times article (Rohter, 2006) illustrates one of the ways that this battle is still being fought: Rio Negro military officers protested lingua geral radio programs by saying they violated Brazilian law against broadcasting in a 'foreign language.' The irony may be lost on many; for most of its history, lingua geral was widely known as 'the Brazilian language' (Cavalcanti, 1883).

\section{References}

Aikhenvald, A. (1999) Tariana Texts and Cultural Context: Languages of the World Text Collections 07, Lincom Europa, München.

Amorim, A. B. ([1926] 1987) Lendas em Nheengatú e em Português, Fundo Editorial ACA, Manaus.

Anderson, R. (1985) 'The caboclo as revolutionary: the Cabanagem Revolt of 1895-1836', in The Amazon Caboclo: Historical and Contemporary Perspectives, Studies in Third World Societies, ed. E. Parker, College of William and Mary, Williamsburg, no. 32, pp. 51-87.

Bakhtin, M. M. (1981) 'Forms of time and chronotope in the novel', The Dialogic Imagination: Four Essays, University of Texas Press, Austin, pp. 84-258.

Baldus, H. ([1964] 1976) 'O xamanismo na aculturação de uma tribo tupí do Brasil Central', in Leituras de Etnologia Brasileira, ed. E. Schaden, Companhia Editora Nacional, São Paulo, pp. 454-462.

Barreto Filho, H. (2004) 'Invenção ou Renascimento?: Gênese de uma Sociedade Indígena Contemporânea no Nordeste', in A Viagem de Volta, ed. J. P. Oliveira, Contracapa, Rio do Janeiro, pp. 93-137.

Campbell, A. T. (1989) To Square with Genesis: Causal Statements and Shamanic Ideas in Wayãpi, University of Iowa Press, Iowa City.

Caspar, F. ([1957] 1976) 'A aculturação dos Tupari', in Leituras de Etnologia Brasileira, ed. E. Schaden, Companhia Editora Nacional, São Paulo, pp. 486-514.

Cavalcanti, A. (1883) The Brasilian Language and its Agglutination, Typographia Nacional, Rio do Janeiro. 
Chernela, J. \& Pinho, P. (2004) 'Constructing a supernatural landscape through talk: creation and recreation in the Central Amazon of Brazil', Journal of Latin American Lore, vol. 22, no. 1, pp. 85-108.

COIAB (2006) 'Coiab pede exoneração do presidente da Funai', Notícias Socioambientais, [online] Available at: http://www.socioambiental.org/nsa/detalhe?id $=2300$

Evans-Pritchard, E. E. ([1937] 1976) Witchcraft, Oracles, and Magic Among the Azande, Clarendon, Oxford.

Fabian, J. (1983) Time and the Other: How Anthropology Makes its Object, Columbia University Press, New York.

Fausto, C. (2002) 'The bones affair: indigenous knowledge practices in contact situations as seen from an Amazonian case', Journal of the Royal Anthropological Institute, vol. 8, pp. 669-690.

Ferreira, R. G. M., Moura, M. M., Engracia, V., Pagotto, R. C., Alves, F. P., Camargo, L. M. A., Pereira da Silva, L. H., Camargo, E. P., Beiguelman, B. \& Krieger, H. (2002) 'Ethnic admixture composition of two Western Amazonian populations', Human Biology, vol. 17, no. 4 , pp. 607-615.

Floyd, S. (2005) 'The poetics of evidentiality in South American storytelling', Santa Barbara Papers in Linguistics, vol. 16, Proceedings from the Eighth Workshop on American Indigenous Languages.

French, J. H. (2004) 'Mestizaje and law making in indigenous identity formation in Northeastern Brazil: "after the conflict came the history", American Anthropologist, vol. 106, no. 4, pp. 663-674.

Galvão, E. ([1964] 1976) 'Encontro de sociedades tribal e nacional no Rio Negro, Amazonas', in Leituras de Etnologia Brasileira, ed. E. Schaden, Companhia Editora Nacional, São Paulo, pp. $420-434$.

Galvão, E. (1979) 'The encounter of tribal and national societies in the Brazilian Amazon', in Brazil: Anthropological Perspectives, eds M. L. Margolis \& W. E. Carter, Columbia University Press, New York, pp. 25-38.

Gomes, M. P. (1988) Os índios e o Brasil, Editora Vozes, Petrópolis.

Gow, P. (1991) Of Mixed Blood: Kinship and History in Peruvian Amazonia, Clarendon, Oxford.

Gow, P. (2003) “"Ex-Cocama”: Indentidades em transfromação na Amazônia peruana', Mana, vol. 9, no. 1, pp. 57-79.

Greene, S. (2005) 'Review of Some Other Amazonians: Perspectives on Modern Amazonia', Journal of Latin American Anthropology, vol. 10, no. 2, pp. 459-460.

Hemming, J. (1987) Amazon Frontier: The Defeat of the Brazilian Indians, Macmillan, London.

Jackson, J. (1983) The Fish People: Linguistic Exogamy and Tukanoan Identity in Northwest Amazonia, Cambridge University Press, Cambridge.

LePage, R. \& Tabouret-Keller, A. (1985) Acts of Identity: Creole-Based Approaches to Language and Ethnicity, Cambridge University Press, Cambridge.

Levi-Strauss, C. ([1955] 1992) Tristes Tropiques, Penguin, Middlesex.

Missão Salesiana do Rio Negro (1961) Discoteca Etno-Lingüístico-Musical dos tribos dos rios Uaupés, Içana e Cauaburi, Centro de Pesquisas de Iaureté, São Paulo.

Moore, D., Facundes, S. \& Pires, N. (1994) 'Nheengatu (Lingua Geral Amazônica), its history, and the effects of language contact', in Survey of Californian and Other Indian Languages, Report 8, Proceedings of the Meetings of the SSILA, July 2-4, 1993.

Moran, E. F. (1974) 'The adaptive system of the Amazonian caboclo', in Man in the Amazon, ed. C. Wagley, University Presses of Florida, Gainesville, pp. 136-159.

Nugent, S. (1993) Amazonian Caboclo Society: An Essay on Invisibility and Peasant Economy, Berg, Oxford.

Nugent, S. (2002) 'Whither O Campesinato? Historical peasantries of the Brazilian Amazonia', Journal of Peasant Studies, vol. 29, no. 3/4, pp. 162-185.

Nugent, S. \& Harris, M. (eds) (2004) Some Other Amazonians: Perspectives on Modern Amazonia, Institute for the Study of the Americas, London. 
Oakdale, S. (2004) 'The culture-conscious Brazilian Indian', American Ethnologist, vol. 31, pp. $60-75$.

Oliveira, J. P. (1999) Ensaios em Antropologia Histórica, Editora UFRJ, Rio do Janeiro.

Oliveira, J. P. (ed.) (2004) A Viagem de Volta: etnicidade, política e reelaboração cultural no Nordeste Indigena, Contracapa, Rio do Janiero.

Oliveira, R. C. (1974) 'Indigenous peoples and sociocultural change in the Amazon', in Man in the Amazon, ed. C. Wagley, University Presses of Florida, Gainesville, pp. 111-135.

Pace, R. (1993) 'First time televiewing in Amazonia: television acculturation in Gurupa, Brazil', Ethnology, vol. 32, no. 2, pp. 187-205.

Pace, R. (1997) 'The Amazon caboclo: what's in a name?', Luso-Brazilian Review, vol. 34, no. 2, pp. 81-89.

Palmié, S. (2002) Wizards and Scientists, Duke University Press, Durham.

Parker, E. (1985a) 'The Amazon caboclo: an introduction and overview', in The Amazon Caboclo: Historical and Contemporary Perspectives, Studies in Third World Societies, ed. E. Parker, College of William and Mary, Williamsburg, no. 32, pp.xvii-li.

Parker, E. (1985b) 'Caboclization: the transformation of the Amerindian in Amazonia 1615-1800', in The Amazon Caboclo: Historical and Contemporary Perspectives, Studies in Third World Societies, no. 32, ed. E. Parker, College of William and Mary, Williamsburg, no. 32, pp. 1-49.

Redfield, R. (1960) The Little Community and Peasant Society and Culture, University of Chicago Press, Chicago.

Reeve, M. E. (2000) 'Concepts of illness and treatment practice in a Caboclo community of the Lower Amazon', Medical Anthropology Quarterly, vol. 14, no. 1, pp. 96-108.

Rohter, L. (2006) 'Language born of colonialism thrives again in Amazon', The New York Times, August 28, [online]. Available at: http://www.nytimes.com/2005/08/28/international/ americas/28amazon.html?ex=1282881600\&en $=2 \mathrm{dbb} 31357 \mathrm{~d} 010164 \& \mathrm{ei}=5090$.

Ruedas, J. (2002) 'Marubo discourse genres and domains of influence: language and politics in an indigenous Amazonian village', International Journal of American Linguistics, vol. 68, no. 4, pp. 447-482.

Saake, G. ([1958] 1976) 'O mito do jurupari entre os Baniwa do Rio Içana', in Leituras de Etnologia Brasileira, ed. E. Schaden, Companhia Editora Nacional, São Paulo, pp. 277-285.

Santos, F. M. \& Oliveria, J. P. (2003) Reconhecimento étnico em exame: dois estudos sobre os Caxixó, Contracapa, Rio do Janeiro.

Schmink, M. (2003) 'No longer invisible, but still enigmatic: Amazonian peasant identities and cosmographies', Reviews in Anthropology, vol. 32, pp. 223-237.

Sherzer, J. (1987) 'A discourse-centered approach to language and culture', American Anthropologist, vol. 89, no. 2, pp. 295-309.

Sherzer, J. (1990) Verbal Art in San Blas: Kuna Culture Through its Discourse, University of New Mexico Press, Albuquerque.

Silva, A. B. A. (1977) A Civilização Indígena do Uaupés: Observações Antropológicas, Etnográficas e Sociológicas, Libreria Ateneo Salesiano, Rome.

Silva, H. P., James, G. D. \& Crews, D. E. (2006) 'Blood pressure, seasonal body fat, heart rate, and ecological differences in Caboclo populations of the Brazilian Amazon', American Journal of Human Biology, vol. 18, pp. 10-22.

Sorenson, Jr, A. P. (1967) 'Multilingualism in the Northwest Amazon', American Anthropologist, vol. 69, pp. 670-684.

Stenzel, K. (2005) 'Multilingualism in the Northwest Amazon, revisited', Proceedings of the Conference on Indigenous Languages of Latin America II, UT Austin.

Szapocznik, J. \& Kurtines, W. (1980) 'Acculturation, biculturalism and adjustment among Cuban Americans', in Acculturation: Theory, Models and Some New Findings. American Association for the Advancement of Science Selected Symposia Series, ed. A. M. Padilla, Westview Press, Boulder, pp. 139-159.

Taylor, G. (1985) 'Apontamentos sobre o neengatu falado no Rio Negro, Brasil', Amerindia, vol. 10, no. 3 , p. 23 . 
Turner, T. (2002) 'Representation, polyphony, and the construction of power in a Kayapó video', in Indigenous Movements, Self-Representation and the State in Latin America, eds K. B. Warren \& J. E. Jackson, University of Texas Press, Austin, pp. 229-250.

Txucarramãe, M. (2006) 'Lideranças Kayapó protestam contra declarações do presidente da Funai', Noticias Socioambientais, January 31, [online] Available at: http://www.socioambiental.org/ nsa/detalhe?id $=2183$

Urban, G. (1991) A Discourse-Centered Approach to Culture: Native South American Myths and Rituals, University of Texas Press, Austin.

Vaz, F. (2006) 'Questão indígena: limpeza étnica e racial no Brasil', CMI Brasil, [online] Available at: http://www.brasil.indymedia.org/pt/blue/2006/02/345098.shtml

Wagley, C. ([1943] 1976) 'Xamanismo tapirapé', in Leituras de Etnologia Brasileira, ed. E. Schaden, Companhia Editora Nacional, São Paulo, pp. 236-237.

Wagley, C. ([1953] 1964) Amazon Town: A Study of Man in the Tropics, Alfred A. Knopf, New York. Wagley, C. (ed.) (1974) Man in the Amazon, University Presses of Florida, Gainesville.

Wallace, A. R. ([1889] 1972) A Narrative of Travels of the Amazon and Rio Negro, Dover, New York.

Warren, J. W. (2001) Racial Revolutions: Antiracism and Indian Resurgence in Brazil. Duke University Press, Durham.

Watson, J. (1953) 'Way station of Westernization: the Brazilian caboclo', in Brazil: Papers Presented in the Institute for Brazilian Studies, Vanderbilt University, eds J. Watson, T. Davidson \& E. Thomas, Vanderbilt University Press, Nashville, pp. 7-55.

Weinstein, B. (1985) 'The persistence of caboclo culture in the Amazon: the impact of the rubber trade, 1850-1920', in The Amazon Caboclo: Historical and Contemporary Perspectives, Studies in Third World Societies, ed. E. Parker, College of William and Mary, Williamsburg, no. 32, pp. 89-113.

Wesche, R. (1985) 'The transformation of rural caboclo society upon integration into Brazil's Amazonian frontier: a study of Itacoatiara', in The Amazon Caboclo: Historical and Contemporary Perspectives, Studies in Third World Societies, ed. E. Parker, College of William and Mary, Williamsburg, no. 32, pp. 115-142.

Simeon Floyd is at the University of Texas at Austin, Department of Anthropology, 1 University Station C3200, Austin, TX 78712, USA (Email: simflo@yahoo.com). 